\title{
"Being in the Zone": A Systematic Review on the Relationship of Psychological Correlates and the Occurrence of Flow Experiences in Sports' Performance
}

\author{
Foteini Stamatelopoulou, Christos Pezirkianidis, Eirini Karakasidou, Agathi Lakioti, \\ Anastassios Stalikas
}

Panteion University of Social and Political Sciences, Athens, Greece

Email: irenekarakasidou@yahoo.com

How to cite this paper: Stamatelopoulou, F., Pezirkianidis, C., Karakasidou, E., Lakioti, A., \& Stalikas, A. (2018). "Being in the Zone": A Systematic Review on the Relationship of Psychological Correlates and the Occurrence of Flow Experiences in Sports' Performance. Psychology, 9, 2011-2030. https://doi.org/10.4236/psych.2018.98115

Received: June 8, 2018

Accepted: August 5, 2018

Published: August 8, 2018

Copyright $\odot 2018$ by authors and Scientific Research Publishing Inc. This work is licensed under the Creative Commons Attribution International License (CC BY 4.0).

http://creativecommons.org/licenses/by/4.0/

\begin{abstract}
Previous research has highlighted the role of internal states in the experience of flow in the sports performance context. This systematic review investigates the relationship between psychological correlates, personality dispositions, traits and internal states (motivation, goals, focus, and arousal) with the experience and occurrence of flow in professional athletes. There have been identified 17 studies published between 2012 and 2017 updating and extending Swann, Keegan, Piggott and Crust's (2012) systematic review. The results indicate that specific psychological correlates, personality traits and dispositions, and internal states are strongly correlated with the appearance of flow. The present study adds to the current research on the sports' flow experience highlighting the importance of constructs, such as confidence, anxiety, commitment, motives, goals, attention, optimal focus and arousal, and the "letting it go" state.
\end{abstract}

\section{Keywords}

Flow, Athletes, Psychological Correlates, Personality Dispositions, Systematic Review

\section{Introduction}

\subsection{Flow Experience and Components}

Were you ever so deeply in what you were doing that you didn't notice anything around you, only to find out that a few hours have gone by without even notic- 
ing it? And you felt that you had experienced your best performance in this activity. This is what can be described as flow, the feeling of "being in the zone"!

Flow is defined as "the intense experiential involvement in moment-to-moment activity, which can be physical or mental. Attention is fully invested in the task at hand and the person functions at her or his fullest capacity" (Csikszentmihalyi, 2009: p. 394). Flow is not just having fun; it is much more specific than that (Landhäuber \& Keller, 2012). Csikszentmihalyi pointed out that there is a set of characteristics, which differentiate actions that activate flow from other types of actions in our everyday lives (Csikszentmihalyi \& Csikszentmihalyi, 1988).

The basic aspects of the flow state are, as outlined by Csikszentmihalyi (1996): 1) a merging of action and awareness, 2) a sense of control, 3) a transformation of time, and 4) an autotelic experience. Important key conditions to facilitate the flow experience are: a) clear goals and immediate feedback in a structured activity, b) balance of challenge versus skills, and c) an autotelic personality. Thus, in the flow experience, attentional resources are fully invested in the task at hand. Furthermore, the loss of self-consciousness and pursuit of clear goals result in the exclusion of thoughts and feelings that people experience as negative. The experience becomes enjoyable and rewarding as we gain a sense of control over what we are doing. Our attention is so fully invested in the task at hand that there is little, or none left over to devote toward the mental processes that contribute to the experience of duration. Finally, we want to repeat the activity for the sake of the experience itself, not expecting external rewards but experiencing an intrinsic motivation towards the activity. The concept of flow, therefore, is based both on the self-determination theory (SDT) and the self-determination continuum as presented by Deci and Ryan (2002), and the autotelic personality concept (Csikszentmihalyi, Rathunde, \& Whalen, 1993).

Rules and a clear outline facilitate flow experiences because they help to orientate the person while feedback gives information that they are on the right pace towards their desired goals. Also, in order to reach and maintain positioning within the flow channel, there must be a delicate balance between our skills and challenges level, otherwise we might experience boredom or apathy (Csikszentmihalyi, 2009; Hefferon \& Bonniwell, 2011). Flow lays as a growth principle in the maintenance of the challenge-skill balance. Commitment and motives towards mastering the challenges and skills drive the person towards practice and gaining expertise in a task (e.g. a sport). That continuum fosters enjoyment and peak performance as a result. The feeling of enjoyment and intrinsic motivation increases the absorption and the interest in a task and creates what we call the flow experience. The notion of the autotelic personality involves individuals whose skills enable them to have an innate general curiosity in life, persistence, low self-centeredness and an ability to be motivated by intrinsic rewards. They are characterized both by receptive qualities (e.g., openness to new experiences) and active qualities (e.g., the tendency to engage in challenging activities) (Csikszentmihalyi et al., 1993). 
We have used Csikszentmihalyi's theoretical framework indicating various associations between the elements that were brought out by the systematic review of Swann and his colleagues (Swann, Keegan, Piggott, \& Crust, 2012). Thus, we included the association between the elements of internal states (motivation, goal and attention) with the basic dimensions of flow theory, namely: the merging of action and awareness, the sense of control and the autotelic experience. Furthermore, we indicated an explicit connection between the psychological correlates of confidence and commitment with those of clear goals, the balance of challenge versus skill, autotelic personality and experience, the merging of action and awareness and the sense of control.

\subsection{Flow in Sports' Environments}

Sports' environments and activities are rich and well-suited performance domains for athletes to experience flow and for researchers to gain understanding of these optimal experiences (Swann, 2016). And that is because they are highly structured, goal directed and rule-bound activities, involving competition and requiring a high level of commitment (Kent, 2006). They also combine physical challenges with mental ones. Flow in sports is also highly associated with peak performance (Jackson \& Roberts, 1992; Landhäuber \& Keller, 2012) and that applies especially to elite athletes.

In sports environments, athletes in flow describe their experience as being totally absorbed in and focused on the task at hand, feeling confident and in control (Jackson, 1995; Jackson \& Csikszentmihalyi, 1999). Most of the research on flow in sport regards measurements of flow after it has occurred and focuses on the association of flow with specific factors, yet without bringing up dimensions of causality. There are three main methods that these measurements have been done: a) interviews, b) questionnaires and c) the Experience Sampling Method (ESM) (Swann, 2016). Interviewing is a qualitative method to explore the subjective experience of flow. Jackson and his colleagues have designed a number of questionnaires to measure dispositional and state flow (Jackson \& Eklund, 2012) which can be utilized to investigate relationships between flow and other variables as well as interventions targeting flow (Swann, 2016). The ESM has limited use in most sports for practical reasons (Kimiecik \& Stein, 1992) because it can be disruptive for measuring flow in sports environments, in a way that can put athletes out "of the zone" during the performance. Another means of categorization proposed by Swann (2016), is the empirical (the experience, the occurrence and the controllability of flow in sport activities, mainly qualitative research) and correlational research (the specific concepts or personality traits which are able to increase the probability for athletes of experiencing flow).

We emphasize on this review on the occurrence of flow in sport. It has been identified as a co-occurrence of internal states (e.g. focus, arousal, motivation, confidence, thoughts and emotions), external factors (e.g. environmental and situational conditions) and behaviors (e.g. preparation) (Swann, 2016). The only systematic review on the flow experience in sports is the one by Swann and his 
colleagues (2012), which focuses on the experience, occurrence and controllability of flow in sports. In that review Swann, Keegan, Piggott, \& Crust, 2012 listed ten factors which could facilitate, prevent or disrupt flow: focus, preparation, motivation, arousal, thoughts and emotions, confidence, environmental and situational conditions, feedback, performance and team play and interaction.

In the domain of personality dispositions and traits, confidence and anxiety (usually researched through the connection with other correlates) have been emphasized as sources that can affect flow. Kimiecik and Stein's (1992) model proposed that psychological factors (like confidence and anxiety) interact with situational factors (like self- and externally paced tasks, opponent ability) in order to "get into the zone" (Koehn, Morris, \& Watt, 2013b). Confidence is an essential element of successful performance and enhances positive experiences in any sport training and competition context. The sport confidence model as presented by Vealey \& Chase (2008) is a state-trait like conceptualization of self-confidence in sport and consists of three basic elements: achievement, self-regulation and social climate. Sports confidence represents a primary mediator of athletes' feelings, thoughts and actions. Confidence is also linked to balance of challenge, skills, and sense of control. Strong confidence allows competitive athletes to frequently experience flow in high-challenge situations (Jackson \& Csikszentmihalyi, 1999). Several other correlates underlie flow in sports: positive correlates like intrinsic motivation and perceived ability (Jackson, Kimiecik, Ford, \& Marsh, 1998), psychological skills and self-concept (Jackson, Thomas, Marsh, \& Smethurst, 2001) and confidence appeared to be connected to flow and, also, a negative correlation emerged between anxiety and flow (Jackson et al., 1998; Koehn, 2013; Stavrou \& Zervas, 2004). Commitment is another source linked to flow, but till now commitment has been researched as an important factor in distinguishing successful athletes from their less successful counterparts (Orlick \& Partington, 1988).

In the internal factors domain, motivation has been identified as the strongest element affecting flow experiences in sport till now. Basic needs-satisfying environmental characteristics interact with dispositional motives to predict intrinsic motivation in sport (Schüler \& Brandstätter, 2013). Here, SDT researchers assume that individual differences in need satisfaction "are not the most fruitful place to focus attention" (Deci \& Ryan, 2000: p. 232), whereas the motive concept is inextricably linked to the notion of interindividual differences. One of these -called motive- is intrinsic to the person and conceptualized as a stable characteristic of that person (a kind of personality disposition). These motives are the achievement motive, the affiliation motive, and the power motive all of which energize, select, and direct behavior (McClelland, 1985). A few studies focus on the motive dispositions in experiencing flow in sports.

These factors have continuously emerged as tools likely to enhance peak-performance, which is (an) ultimate goal in sports environments. Thus, both the increasing emphasis on flow within current sports-literature and the focus of the present review are justified. 
What has emphatically emerged from the studies of the past five years is the possible association between psychological correlates, personality dispositions and specific internal factors (focus, arousal, and motivation) that can promote the flow experience in athletes. Thereby, the present review aimed to identify the attributes that enhance flow. Practically, we wanted to equip coaches and athletes with tools that can positively influence sport performance.

\section{Method}

In order to examine the relationship between psychological correlates, personality dispositions and traits, internal states and psychological flow in sports environments we used the following search terms: "psychological correlates" OR "personality traits" OR "personality dispositions" AND "internal states" OR "focus" OR "motivation" OR "arousal" AND "psychological flow" OR "flow" OR "optimal experience" OR "peak performance" AND "sports" flow" OR "flow in sport". Data were collected using the Heal-link database to access Scopus, ResearchGate, PsycNET, Springer and Google Scholar. First, we examined the titles and abstracts of relevant articles and selected those that were focused on our chosen variables. We used the following inclusion criteria to select studies: 1) the study has been published between 2012 and 2017, 2) the article is written in English and 3) the study can be tracked online by a digital object identifier (DOI).

Thirty articles have been identified. Five of them were excluded because of their year of publication and eight because of their irrelevant correlates. Thus, 17 studies were included in the analysis, which had a strong connection with the correlates we have chosen to highlight (psychological correlates and personality traits, internal states, experience of flow) and their validity was controlled by a digital object identifier (DOI).

\section{Results}

\subsection{Flow in Sport, Psychological Correlates and Personality Traits}

The first eleven studies (Table 1) are focused on the psychological correlates and personality traits linked to flow in sports environments.

A strong correlation was found between confidence and flow on several studies (Crust \& Swann, 2013; Jackman, Hout, Lane, \& Fitzpatrick, 2014; Koehn, 2013; Koehn, Morris, \& Watt, 2013a; Koehn, Morris, \& Watt, 2013b; Koehn, Pearce, \& Morris, 2013; Swann, Keegan, Crust, \& Piggot, 2016; Swann, Piggot, Crust, Keegan, \& Hemmings, 2015). More specifically, confidence as a dimension of mental toughness (MT) found to be strongly correlated with the flow components: sense of control, challenge and skill balance. In the same study, high levels of confidence and challenge predicted the frequency of flow (Crust \& Swann, 2013). It has also been proposed that confidence is positively connected to flow and that it could be a protective factor against anxiety interpretations (Koehn, 2013). Specifically, sports confidence has also been found to mediate the relationship between self-regulation, achievement and flow (Koehn et al., 2013). 
Table 1. Results: Review of the studies focused on psychological correlates and personality traits linked to flow in sports environments.

\begin{tabular}{|c|c|c|c|c|}
\hline Study & Design \& Aim & Method & Sample & Key Findings \\
\hline $\begin{array}{l}\text { 1) } \\
\text { Crust \& } \\
\text { Swann (2013) }\end{array}$ & $\begin{array}{l}\text { Cross-sectional study } \\
\text { Aim: To examine the } \\
\text { relationship between mental } \\
\text { toughness (MT) and } \\
\text { dispositional flow }\end{array}$ & $\begin{array}{l}\text { Mental Toughness } \\
\text { Questionnaire } 48 \\
\text { (MTQ48) and } \\
\text { Dispositional } \\
\text { Flow Scale-2 (DFS-2) }\end{array}$ & $\begin{array}{l}135 \text { athletes from } \\
\text { University and local } \\
\text { sports teams } \\
\text { (i.e. soccer, rugby, } \\
\text { netball, hockey). } \\
\text { (104 men, } 31 \text { women) } \\
\text { Mage }=20.81 \text { years, } \\
S D=2.76 \text {; } \\
M \text { experience }=9.34 \text { years, } \\
S D=5.43\end{array}$ & $\begin{array}{l}\text { Strong correlation between MT } \\
\text { dimension, confidence and the } \\
\text { components of flow: a sense } \\
\text { of control }(r=.68 ; p<.001) \\
\text { and skill balance } \\
\text { ( } r=66 ; p<.001) \text {. Also, positive } \\
\text { correlations emerged between } \\
\text { total MT and global flow } \\
(r=0.65, p<.001) \text { and } \\
\text { significant correlations } \\
\text { appeared between subscales of } \\
\text { MTQ48 and DFS-2 } \\
(r=.26 \text { to } .68 ; p<.01) \text {. } \\
\text { High levels of confidence } \\
\text { and challenge can predict } \\
\text { the frequency of flow. }\end{array}$ \\
\hline $\begin{array}{l}\text { 2) } \\
\text { Koehn (2013) }\end{array}$ & $\begin{array}{l}\text { Cross-sectional study } \\
\text { Aim: Potential direct and } \\
\text { indirect effects of } \\
\text { confidence and anxiety } \\
\text { dimensions on flow state } \\
\text { in tennis competition. }\end{array}$ & $\begin{array}{l}\text { Competitive State } \\
\text { Anxiety Inventory-2 d } \\
\text { (CSAI-2d), and Flow } \\
\text { State Scale-2 (FSS-2) }\end{array}$ & $\begin{array}{l}59 \text { junior tennis players } \\
(35 \text { boys, } 24 \text { girls) } \\
\text { Mage }=14.03, S D=1.40 ; \\
M \text { competition years } \\
=3.95, S D=1.42 ; \\
M \text { training hours per } \\
\text { week }=5.36, S D=3.60\end{array}$ & $\begin{array}{l}\text { CSAI- } 2 \mathrm{~d} \text { showed significant } \\
\text { positive correlations with } \\
\text { eight } \text { flow subscales } \\
(r=.72, p<.01) \text {, expect time } \\
\text { transformation. Flow dimensions } \\
\text { showed negative links with anxiety } \\
\text { constructs, more so with cognitive } \\
(r=-.21, p<.01) \text { than with } \\
\text { somatic }(r=-.20, p<.01) .\end{array}$ \\
\hline $\begin{array}{l}\text { 3) } \\
\text { Koehn, Pearce, } \\
\text { \& Morris (2013) }\end{array}$ & $\begin{array}{l}\text { Cross-sectional study } \\
\text { Aim: To examine } \\
\text { the mediation of } \\
\text { confidence between sources } \\
\text { of sport } \\
\text { confidence } \\
\text { (including achievement, } \\
\text { self-regulation, and } \\
\text { social climate) and } \\
\text { athletes' affect in } \\
\text { competition }\end{array}$ & $\begin{array}{l}\text { Sources of Sport } \\
\text { Confidence } \\
\text { Questionnaire, } \\
\text { Trait Sport } \\
\text { Confidence } \\
\text { Inventory (TSCI) } \\
\text { and DFS-2 }\end{array}$ & $\begin{array}{l}386 \text { athletes from } \\
\text { various sports } \\
\text { (football, rugby, } \\
\text { basketball, swimming } \\
\text { and hockey) } \\
(257 \text { men, } 129 \text { women) } \\
\text { Mage }=20.69, S D=3.17 \\
M \text { experience }=10.14 \text { years, } \\
S D=4.92 ; \\
M \text { competition }=8.14 \text { years; } \\
S D=4.22\end{array}$ & $\begin{array}{l}\text { Small significant correlations } \\
\text { were found between } \\
\text { sources of confidence } \\
\text { and sport confidence } \\
(r=.15, p<.01) \text { and } \\
\text { dispositional flow }(r=.24, p<.01) . \\
\text { The only significant predictor of } \\
\text { confidence appeared was } \\
\text { achievement, } b=.15, p<.05 . \\
\text { On a subscale level, confidence } \\
\text { showed moderate to strong } \\
\text { association with flow dimensions } \\
\text { of challenge-skills balance } \\
\text { ( } r=.60, p<.001) \text {, sense of control } \\
\text { ( } r=.46, p<.001) \text {, and concentration } \\
\text { on the task at hand ( } r=.42, p<.001) .\end{array}$ \\
\hline $\begin{array}{l}\text { 4) } \\
\text { Koehn, } \\
\text { Morris, \& Watt } \\
\text { (2013a) }\end{array}$ & $\begin{array}{l}\text { Cross-sectional study } \\
\text { Aim: To investigate } \\
\text { the relationship between } \\
\text { psychological correlates } \\
\text { and flow in tennis } \\
\text { competition }\end{array}$ & $\begin{array}{l}\text { DFS-2, FSS-2, } \\
\text { Marlowe-Crowne } \\
\text { Social Desirability } \\
\text { Scale-Short Form } \\
\text { (MCSDS-SF), Action } \\
\text { Control Scale-Sport } \\
\text { (ACSS), Sport Imagery } \\
\text { Questionnaire (SIQ), } \\
\text { Tellegen Absorption } \\
\text { Scale (TAS), and TSCI }\end{array}$ & $\begin{array}{l}261 \text { junior tennis players } \\
(180 \text { boys, } 81 \text { girls }) \\
\text { Mage }=14.34, \\
S D=1.57 ; \text {, } \text { years in } \\
\text { tennis competitions }=4.28, \\
S D=1.86 ; \\
M \text { training hours per } \\
\text { week }=9.01, S D=5.87\end{array}$ & $\begin{array}{l}\text { Moderate to strong correlations } \\
\text { found between dispositional flow } \\
\text { and trait confidence }(r=.59 ; p<.001) \text {, } \\
\text { imagery use }(r=.58 ; p<.001), \\
\text { and action control }(r=.41 ; p<.001) .\end{array}$ \\
\hline
\end{tabular}




\section{Continued}

\begin{tabular}{|c|c|c|c|c|}
\hline & Repeated-measures design & & & \\
\hline $\begin{array}{l}\text { 5) } \\
\text { Koehn, Morris, } \\
\text { \& Watt (2013b) }\end{array}$ & $\begin{array}{l}\text { Aims: } \\
\text { 1) To examine main and } \\
\text { interaction effects between } \\
\text { imagery use and confidence } \\
\text { on flow state in different } \\
\text { performance contexts, } \\
\text { 2) To assess main and } \\
\text { interaction effects between } \\
\text { flow state, imagery, and } \\
\text { confidence on self-paced } \\
\text { service and externally-paced } \\
\text { groundstroke performance } \\
\text { in tennis }\end{array}$ & $\begin{array}{l}\text { FSS-2, SIQ, } \\
\text { TSCI } \\
\text { Performance was } \\
\text { measured through } \\
\text { shot accuracy, which } \\
\text { was based on a } \\
\text { point system } \\
\text { ranging between } \\
24 \text { and } 96 \text { points }\end{array}$ & $\begin{array}{l}60 \text { junior tennis players } \\
\text { frequently competed in } \\
\text { tennis tournaments } \\
\text { Mage }=13.83, S D=1.45 ; \\
\text { Myears playing tennis }= \\
5.83 ; \text { M hours of training } \\
\text { per week }=7.57 \text {. }\end{array}$ & $\begin{array}{l}\text { A significant correlation between } \\
\text { imagery } \mathrm{x} \text { confidence was found for } \\
\text { flow state in the groundstroke } \\
\text { ( } p \text { value }=.04, p<.05) \\
\text { but not in the service task } \\
(p=.27, p<.05) . \\
\text { Flow state appeared to have a little } \\
\text { higher significance in the } \\
\text { externally- paced groundstroke } \\
\text { performance }(r=.33 ; p<.05) \\
\text { than in the self-paced task service } \\
\text { performance }(r=.28 ; p<.05) .\end{array}$ \\
\hline $\begin{array}{l}\text { 6) } \\
\text { Fullager, Knight, } \\
\text { \& Sovern (2013) }\end{array}$ & $\begin{array}{l}\text { Longitudinal } \\
\text { study } \\
\text { Aim: To examine the } \\
\text { relationship among } \\
\text { challenge/skill } \\
\text { balance, flow, and } \\
\text { performance anxiety }\end{array}$ & $\begin{array}{l}\text { Per week after } \\
\text { practicing, students } \\
\text { answered the FSS-2 } \\
\text { and a series of } \\
\text { questions that } \\
\text { assessed: } \\
\text { 1) the perceived } \\
\text { challenge ( } 2 \text { items), } \\
\text { 2) perceived skill } \\
\text { (2 items), and } \\
3 \text { ) anxiety } \\
\text { (single-item) while } \\
\text { playing each passage } \\
\text { of the music piece }\end{array}$ & $\begin{array}{l}27 \text { music university } \\
\text { students } \\
(14 \text { men, } 13 \text { women }) \\
\text { Mage = } 21.71 \text { years; } \\
\text { MNo of recitals given = } \\
3.59, S D=3.32\end{array}$ & $\begin{array}{l}\text { Flow and performance anxiety } \\
\text { appeared } \\
\text { to be negatively correlated } \\
(r=-.57, p<.05) \text {. Also, significant } \\
\text { negative correlation } \\
\text { emerged between flow and } \\
\text { challenge/skill balance } \\
(r=-.62, p<.05) \text {. }\end{array}$ \\
\hline $\begin{array}{l}\text { 7) } \\
\text { Swann, Keegan, } \\
\text { Piggot, Crust, \& } \\
\text { Smith (2012) }\end{array}$ & $\begin{array}{l}\text { Qualitative study, } \\
\text { Aim: To investigate } \\
\text { the occurrence of } \\
\text { flow in elite golfers }\end{array}$ & $\begin{array}{l}\text { Semi-structured } \\
\text { interviews }\end{array}$ & $\begin{array}{l}13 \text { male professional golfers } \\
\text { Mage }=33.5 \text { years, } \\
S D=9.28 \\
\text { Mexperience }=11.8 \\
\text { years, } S D=10.28\end{array}$ & $\begin{array}{l}\text { Facilitators of flow found to be: } \\
\text { motivation to perform, effective } \\
\text { preparation, appropriate focus, } \\
\text { positive state, letting it happen, } \\
\text { psychological interventions, optimal } \\
\text { environmental and situational } \\
\text { conditions, optimal arousal, } \\
\text { maintenance of physical state, } \\
\text { pre-shot routine, and playing well. }\end{array}$ \\
\hline $\begin{array}{l}\text { 8) } \\
\text { Swann, Piggot, } \\
\text { Crust, Keegan, } \\
\text { \& Hemmings } \\
(2015)\end{array}$ & $\begin{array}{l}\text { Qualitative study } \\
\text { Aim: To explore the } \\
\text { specific ways in } \\
\text { which facilitators } \\
\text { influenced flow } \\
\text { occurrence in } \\
\text { European } \\
\text { Tour golfers }\end{array}$ & $\begin{array}{l}\text { Semi-structured } \\
\text { Interviews } \\
\text { Data were interpreted } \\
\text { using an iterative } \\
\text { process of thematic } \\
\text { and connecting ana- } \\
\text { lyses }\end{array}$ & $\begin{array}{l}10 \text { male professional } \\
\text { golfers who had all played } \\
\text { full-time on the European } \\
\text { Tour for at least } \\
\text { one full season. }\end{array}$ & $\begin{array}{l}10 \text { facilitators of flow were identified, } \\
\text { of which commitment and the caddie } \\
\text { have not been reported previously, and } \\
\text { confidence and concentration also } \\
\text { emerged as key constructs. } \\
24 \text { connecting links were identified } \\
\text { in the data, through which the caddie, } \\
\text { effective preparation, and high-quality } \\
\text { performance appeared to be most } \\
\text { influential for flow occurrence. }\end{array}$ \\
\hline $\begin{array}{l}\text { 9) } \\
\text { Swann, Keegan, } \\
\text { Crust, \& Piggot } \\
\text { (2016) }\end{array}$ & $\begin{array}{l}\text { Mixed-method } \\
\text { multiple case study } \\
\text { Aim: To better } \\
\text { understand the } \\
\text { occurrence and } \\
\text { experience of } \\
\text { flow in elite golf }\end{array}$ & $\begin{array}{l}\text { 1) direct } \\
\text { observations, } \\
\text { 2) performance data, } \\
\text { and } \\
\text { 3) interviews }\end{array}$ & $\begin{array}{l}10 \text { male professional golfers. } \\
4 \text { players had competed } \\
\text { full-time on the European } \\
\text { Tour } 2,2 \text { had won } \\
\text { European Tour events. } \\
2 \text { had competed full-time } \\
\text { on the Challenge Tour, } \\
\text { with nine Challenge Tour } \\
\text { wins between them. }\end{array}$ & $\begin{array}{l}2 \text { different states were described as: } \\
\text { 1) "letting it happen" which } \\
\text { corresponded with the definition } \\
\text { and description of flow; and } \\
\text { 2) "making it happen" which was } \\
\text { more effortful and intense, involved a } \\
\text { heightened awareness of the situation. }\end{array}$ \\
\hline
\end{tabular}




\begin{tabular}{|c|c|c|c|c|}
\hline $\begin{array}{l}\text { 10) } \\
\text { Jackman, } \\
\text { Hout, Lane, \& } \\
\text { Fitzpatrick } \\
(2014)\end{array}$ & $\begin{array}{l}\text { Qualitative study } \\
\text { Aim: To explore the } \\
\text { conditions } \\
\text { that: } \\
\text { (a) facilitate, } \\
\text { (b) inhibit and } \\
\text { (c) disrupt the occurrence } \\
\text { of flow in flat horse racing }\end{array}$ & $\begin{array}{l}\text { Semi-structured inter- } \\
\text { views. } \\
4 \text { distinct sections: } \\
\text { (a) background and } \\
\text { career history } \\
\text { (b) flow } \\
\text { (c) flow inhibition and } \\
\text { (d) flow disruption }\end{array}$ & $\begin{array}{l}10 \text { Irish professional male } \\
\text { Flat jockeys } \\
\text { Mage }=27.4 \text { years, } \\
S D=7.14 \\
M \text { career length }=9.16 \text { years, } \\
S D=5.9 ; \text { M number } \\
\text { of race wins }=31.94 \\
S D=15.99 \text { ( } 2012 \text { season })\end{array}$ & $\begin{array}{l}\text { the essence of the flow experience: } \\
\text { environmental and situational } \\
\text { conditions, experience interaction } \\
\text { with trainer/owner, physical } \\
\text { readiness, effective preparation, } \\
\text { performance assessment } \\
\text { confidence, optimal arousal, } \\
\text { focus, motivation, horse demeanor } \\
\text { and performance and relationship } \\
\text { between horse and jockey. }\end{array}$ \\
\hline $\begin{array}{l}\text { 11) } \\
\text { Aubé, Brunelle, } \\
\text { \& Rousseau } \\
(2014)\end{array}$ & $\begin{array}{l}\text { Cross-sectional study } \\
\text { Aim: To test the } \\
\text { relationships between } \\
\text { flow experience, team } \\
\text { goal commitment and } \\
\text { team performance. }\end{array}$ & $\begin{array}{l}\text { 9-item Flow Scale, } \\
\text { Information exchange } \\
\text { ( } 2 \text { items), Team goal } \\
\text { commitment ( } 3 \text { items), } \\
\text { Team performance } \\
\text { potential control } \\
\text { variable }\end{array}$ & $\begin{array}{l}85 \text { teams ( } 395 \text { members) of } \\
\text { undergraduate and graduate } \\
\text { students from a Canadian } \\
\text { business school participating } \\
\text { in a project management } \\
\text { simulation as part of their } \\
\text { course work. Team size } \\
\text { varied from } 4 \text { to } 6 \text { members. } \\
49 \% \text { women, } 51 \% \text { men; } \\
\text { Mage }=28.7 \text { years, } S D=6.5\end{array}$ & $\begin{array}{l}\text { Flow experience is positively related to } \\
\text { team performance }(r=.40, p<.01) . \\
\text { This relationship is mediated by team } \\
\text { goal commitment ( } 3 \text { models analysis, } \\
\text { p.125) } \\
\text { and moderated by the level of } \\
\text { information exchange between } \\
\text { team members } \\
\left(\Delta R^{2 \prime}=.044, p<.01 \text {, Table } 3, \mathrm{p} .126\right) \text {. }\end{array}$ \\
\hline
\end{tabular}

In a second study by the same researchers it was revealed that confidence and imagery use had a correlation for tennis players' flow state in groundstroke (externally-paced task) and not in the service task (self-paced task) (Koehn et al., 2013b). Swann et al. (2016) described in their study two different states: the "letting it happen" state, which was a relatively gradual build-up of confidence and a flow-like feeling, and the "making it happen" state which was a more sudden steeping-up of concentration and effort. In a recent study, commitment and caddie (a person who carries a golfer's clubs and provides other assistance during a match) were found to be facilitators of flow, while confidence and concentration were key constructs of flow (Swann et al., 2015). Finally, confidence was also found to be one of the 12 conditions affecting flow in horse racing (Jackman et al., 2014).

Another psychological correlate of flow that has been highlighted in studies is anxiety (Table 1). Flow and performance anxiety are antithetical experiences, representing states and not traits and are both affected by circumstances (Fullager, Knight, \& Sovern, 2013). Positive state emerged as another psychological correlate of flow. Positive state was found to be one of the most important facilitators of the sports' flow experience (Swann, Keegan, Piggott, Crust, \& Smith, 2012). A calm and relaxed state was also introduced as an important flow correlate which is strongly linked with the "letting it go" state (Swann et al., 2016). Finally, commitment was highlighted in several studies as an important component of the flow experience in sports environments (Aubé, Brunelle, \& Rousseau, 2014; Swann et al., 2015). Commitment emerged as one of the facilitators of flow, important also to the enhancement of confidence. An interesting finding is that commitment appeared as an essential factor in individual sports (Swann et 
al., 2015). Swann et al. (2015) have identified 24 facilitators of the flow experience including effective preparation, caddie and high-quality performance. Moreover, the only finding focusing on team flow proposed a possible relationship between flow and team performance which was found to be mediated by team goal commitment and information exchange between team members (Aubé et al., 2014).

\subsection{Flow in Sport and Internal States}

The next five studies (Table 2) emphasized the internal states that facilitate the flow experience. The term internal states on flow in sports were taken by Swann (2016) and refer to focus, arousal, motivation, confidence, thoughts and emotions. In this review we include only the internal states correlates of motivation and focus-attention, adding also goals as a new element in this category due to its direct link with motivation.

The first two studies (references) are focused on the motivation aspect of the flow experience. The first study showed the connection between need satisfaction and flow and highlighted the fact that individuals with high achievement motivation can be positively affected and "be in the zone" in more individualistic sports environments while, on the other hand, individuals that appear to be affiliation-motivated can benefit more from team and interaction sports environments (Schüler \& Brandstätter, 2013). The study of Schüler, Wegner and Knechtle (2014) also highlighted the fact that individuals with high achievement motivation benefited more from the fulfillment of the need for competence satisfaction in a sport flow experience and especially in an endurance sports environment and stated again that affiliation-motivated individuals benefited more from team sports and recreational sports. In the second category of the internal states findings, goals appeared as another important facilitator of the flow sports experience. In a relevant study it was suggested that performance-avoidance goals can function as regulatory factors for individuals with high avoidance temperament experience to control the anxiety factors that can be generated from achievement environments and that type of temperament can help in experiencing higher flow experiences (Oertig, Schüler, Brandstätter, \& Augustine, 2014). More generally, Koehn and Morris (2014) found that club players' involvement in performance contexts was mainly based on intrinsic reasons, whereas ranking list players reported intrinsic reasons for training and extrinsic reasons for competition states. Finally, focus-attention was identified as a facilitator that should be included in the internal states that promote flow experiences in sports. A study highlighted that external (flow-feeling attentional mode) and internal (focused at the basic aspects of action and not at fatigue) associative focus- attention strategies can facilitate the performance in a competition environment (Bertollo et al., 2015).

\subsection{Experience of Flow in Sport}

The studies reported in Table 3 focus on the way that flow is experienced in 
Table 2. Results: Review of the studies focused on the internal states that can facilitate the flow experience.

\begin{tabular}{|c|c|c|c|c|}
\hline Study & Design \& Aim & Method & Sample & Key Findings \\
\hline $\begin{array}{l}\text { 12) } \\
\text { Schüler \& } \\
\text { Brandstätter } \\
\text { (2013) }\end{array}$ & $\begin{array}{l}\text { Correlational } \\
\text { and experimental } \\
\text { study designs } \\
\text { Aim: To examine the } \\
\text { effect of need satisfaction } \\
\text { on flow. And to examine } \\
\text { the effect of competence } \\
\text { need satisfaction is } \\
\text { moderated by the } \\
\text { achievement motive } \\
\text { and if the effect of } \\
\text { need-for-relatedness } \\
\text { satisfaction is moderated } \\
\text { by the affiliation motive } \\
\text { in different } \\
\text { sports domains. }\end{array}$ & $\begin{array}{l}4 \text { studies were } \\
\text { conducted in different } \\
\text { sport domains } \\
\text { (badminton, fitness, } \\
\text { volleyball). } \\
\text { Multi-Motive-Grid } \\
\text { (MMG), Competence } \\
\text { environment ( } 3 \text { items), } \\
\text { Flow Short Scale }\end{array}$ & $\begin{array}{l}\text { 1: } 61 \text { male and } 33 \text { female } \\
\text { advanced badminton } \\
\text { players Mage }=20.6 \\
\text { years, } S D=1.1 \\
\text { 2: } 78 \text { undergraduate } \\
\text { students without any } \\
\text { experience in volleyball } \\
\text { (60 women) Mage }=25 \\
\text { years, } S D=6.12 \\
\text { 3: } 695 \text { students and } \\
\text { alumni were recruited } \\
\text { from university fitness } \\
\text { courses (409 females) } \\
\text { Mage }=32 \text { years, } S D= \\
\text { 9.97 } \\
\text { 4: } 262 \text { members of } \\
\text { sports clubs } \\
\text { Mage }=33.5, S D=10.4\end{array}$ & $\begin{array}{l}\text { 1: Achievement motive associated with } \\
\text { the competence environment }(r=.23, \\
p<.05) \text { and flow experience }(r=.21, p \\
<.05) \text {. Competence environment related } \\
\text { to the flow experience }(r=.25, p<.001) \text {. } \\
\text { 2: Achievement motive (competence } \\
\text { condition) positively correlated to flow } \\
(r=.26) \text {, achievement motive (control } \\
\text { group) negatively related to flow } \\
(r=-.32) \text {. } \\
\text { 3: Competence (need satisfaction) } \\
\text { appeared to be significantly correlated to } \\
\text { AFF motive ( } r=.15, p<.01) \text { more than } \\
\text { ACH motive }(r=.06) \text {, and relatedness } \\
\text { (need satisfaction) isn't significantly } \\
\text { correlated to AFF motive }(r=.07) \\
\text { and ACH motive }(r=.05) \text {. } \\
4: \text { Competence (need satisfaction) } \\
\text { appeared to be significantly correlated } \\
\text { to AFF motive }(r=-.19, p<.05) \text {. }\end{array}$ \\
\hline
\end{tabular}

Cross-sectional Study

Aim: To test whether the implicit achievement and

13)

Schüler, Wegner, \& Knechtle (2014)

14)

Oertig, Schüler, Brandstätter, \& Augustine (2014) affiliation motives interact with the need for competence and the need for social relatedness satisfaction, flow experience and well-being in extreme sports.

Laboratory and naturalistic study Aim: To examine the joint influence of avoidance temperament and avoidance-based the experience of flow on a creativity task respectively, to predict achievement goals on

\section{Pilot study:}

Picture Story Exercise

(PSE), Sheldon \&

Hilpert's Balanced

Measure of

Psychological Needs,

Flow Short Scale

Main study.

The above plus

Exercise

Addiction Inventory

The indicators of avoidance temperance were BIS sensitivity (Study 1) and neurotism (Study 2) Study 1: Randomly assigned to one of four goal conditions (2 V 2 achievement goal framework) and then given a verbal creativity task (Flow Short Scale and BIS sensitivity scale) Study 2: Different creativity task and avoidance temperament was operationalized in terms of individual differences in neuroticism (NEO

Five-Factor Inventory)

\section{Pilot study.}

29 ultra-endurance athletes (long-distance runners, triathletes, long-distance bikers; 24 men) Mage $=47.5$ years, $S D=7.85$

\section{Main study.}

93 German-speaking long-distance runners (73 men) Mage $=47.7$, $S D=9.46$

Study 1: 101 university students from Switzerland (74.3\% women) Mage $=22.61$ years, $S D=4.03$

Study 2: 102 high school students from Switzerland ( $48.0 \%$ females) Mage $=16.23$ years, $S D=1.13$
Achievement and affiliation motive were unrelated $(r=.02)$. Achievement motive was significantly related to relatedness satisfaction $(r=.22, p<.05)$. Basic need for competence and relatedness satisfaction were associated with each other $(r=.68, p<.001)$ and with flow $(r=.23, r=.26, p<.05)$ on a highly significance level.
Study 1: No significant correlations between BIS sensitivity and baseline flow $(r=-.14, p=.16)$ or post-manipulation flow $(r=.01, p=.94)$.

Study 2: Significant correlation between neuroticism and baseline flow $(r=-.17, p=.09)$ and no correlation between neuroticism and post-manipulation flow $(r=-.03, p=.78)$. 


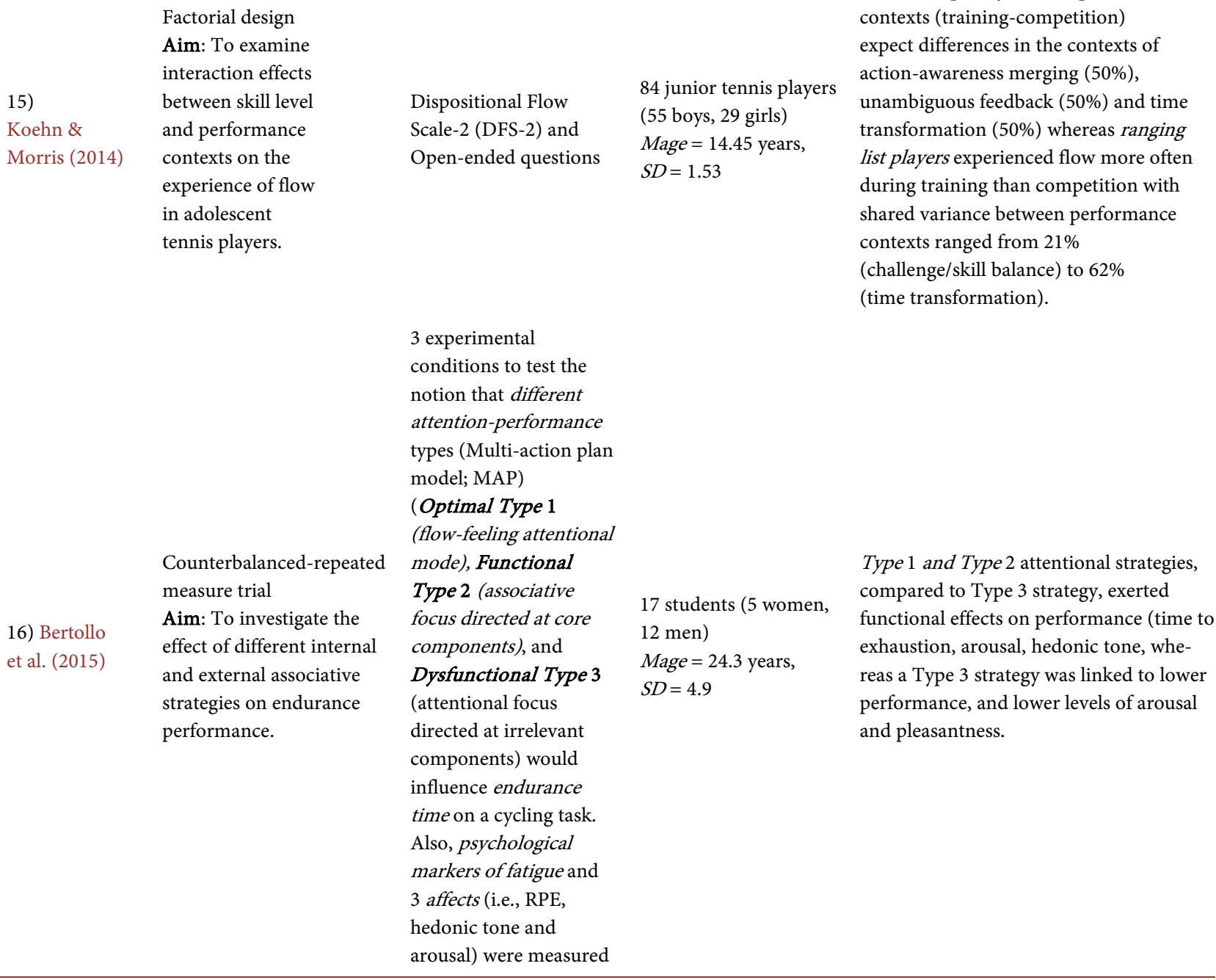

Table 3. Results: Review of the studies focused on the way that flow is experienced on sports environments.

\begin{tabular}{|c|c|c|c|c|}
\hline Study & Design \& Aim & Method & Sample & Key Findings \\
\hline $\begin{array}{l}\text { 17) } \\
\text { Swann, Crust, } \\
\text { Keegan, } \\
\text { Piggot, \& } \\
\text { Hemmings } \\
(2015)\end{array}$ & $\begin{array}{l}\text { Qualitative Research } \\
\text { Aim: To explore } \\
\text { perceptions regarding } \\
\text { the experience of } \\
\text { flow in elite golf }\end{array}$ & $\begin{array}{l}\text { Semi-structured } \\
\text { interviews }\end{array}$ & $\begin{array}{l}10 \text { male professional golfers. } \\
\text { They held a European Tour } \\
\text { card for at least one full season } \\
\text { (range }=1-24 ; 6 \text { seasons; } \\
M=10.7 ; S D=7.5) \text {. } \\
\text { Ages ranging from } 23 \text { to } 58 \\
(S D=13.08)\end{array}$ & $\begin{array}{l}\text { Golfers reported being aware of flow experiences } \\
\text { and able to manage them. They stated that altered } \\
\text { cognitive and kinesthetic perceptions, visualizing } \\
\text { well, visual narrowing, magnified visual } \\
\text { perceptions, altered perceptions of time, loss of } \\
\text { memory, sense of lightness, feel enhanced } \\
\text { physically, feeling calm/relaxed, feeling the } \\
\text { adrenaline were generated and that flow was } \\
\text { observable (e.g. through changes in behavior). }\end{array}$ \\
\hline
\end{tabular}

sports environments A basic study, revealing the main findings on the factors that facilitate flow, is that by Swann et al. (2015), who found 11 factors leading to flow: among them where motivation to perform, appropriate focus, letting it happen, optimal arousal. To add in this section, a new study (Swann et al., 2015, 
Table 3) highlighted a novel category on the flow framework, that one of altered cognitive and kinesthetic perceptions among others (visualizing well, visual narrowing, magnified visual perceptions, altered perceptions of time, loss of memory, sense of lightness, feel enhanced physically, feeling calm/relaxed, feel the adrenaline) in golfers. Another important finding in the same study concerns the observability of flow and the fact that golfers reported being aware when they were in flow and able to manage it.

\subsection{Flow in Sport Interventions}

Finally, we summed up three main intervention studies (Table 4) which were conducted during the past five years. The first one is by Briegel-Jones, Knowles, Eubank, Giannoulatos and Elliot (2013) which examined the effects of a 10-week yoga intervention on mindfulness and flow of elite youth swimmers. The intervention had a positive impact on a range of physiological, cognitive and performance parameters that included elements of mindfulness and flow. The second one by Hutchinson, Karageorghis and Jones (2014) investigated the influence of music and music-video on a range of psychological and psychophysical variables and found that the music and video condition elicited the highest levels of dissociation, lowest RPE (Rated Perceived Exertion), and most positive affective responses regardless of exercise intensity. Finally, Bortoli, Maurizio, Hanin and Robazza (2012) designed a multi-action plan intervention (MAP) and tested its influence on the optimal experiences of the Italian Olympic shooting team. The intervention affected the individual's awareness of the flow experience and the strength to overcome stressful conditions during shooting, similar to those in competition. Emotion-focused strategies (incorporated in the MAP intervention) targeting direct emotions and self-regulation can facilitate levels of the competitive self-confidence, anxiety, and pleasant/ unpleasant emotional states and promote optimal experiences.

\section{Discussion}

Our review aimed to investigate the connection between psychological correlates, personality traits and dispositions, and the experience of flow in athletes. The main findings to emerge from this review is that psychological correlates and personality traits like confidence, anxiety, positive state, calm and relaxed state and commitment appear to be important factors associated with the flow experience in sports. These findings can be also found in Swann and his colleagues' (2012) systematic review. However, more in-depth results the past years provide us a greater insight on the different states and emotions aspects and on the different types of athletes' groups (age, experience, single or team environment) and needs that appear on a complex sports' environment.

The results indicate that one of the main relationships investigated on most of the studies conducted the past five years was the relationship between confidence and flow in sports' environments. Athletes who are engaged, committed, 
Table 4. Results: Review of the intervention studies.

\begin{tabular}{|c|c|c|c|}
\hline Study & Design \& Aim & Method & Sample \\
\hline $\begin{array}{l}\text { 18) } \\
\text { Briegel-Jones, } \\
\text { Knowles, } \\
\text { Eubank, } \\
\text { Giannoulatos, } \\
\text { \& Elliot (2013) }\end{array}$ & $\begin{array}{l}\text { Mixed methods design } \\
\text { Aim: To examine the } \\
\text { effects of a } 10 \text {-week } \\
\text { yoga intervention on } \\
\text { mindfulness and } \\
\text { dispositional flow of } \\
\text { elite youth swimmers }\end{array}$ & $\begin{array}{l}\text { Qualitative Survey } \\
\text { (10-week Sivananda } \\
\text { Yoga Program), } \\
\text { Child and Adolescent } \\
\text { Mindfulness Measure } \\
\text { (CAMM) and DFS-2 }\end{array}$ & $\begin{array}{l}21 \text { elite youth swimmers } \\
\text { (10 males, } 11 \text { females; } \\
M \text { age = } 13.24 \text { years, } \\
S D=1.51 \text { years) } \\
\text { selected from two } \\
\text { affiliated national } \\
\text { training sites of the } \\
\text { Amateur Swimming } \\
\text { Association in the UK }\end{array}$ \\
\hline
\end{tabular}

19)

Hutchinson, Karageorghis, \& Jones (2014)

20)

Bortoli, Bertollo,

Hanin, \&

Robazza (2012)
Cross-sectional study Aim: To examine the effects of music and music-video on a range of psychological and psychophysical variables during treadmill running at intensities above and below ventilatory threshold (VT).
Participants exercised at $10 \%$ of maximal capacity below VT and 10\% above under music-only, music-video, and control conditions. Feeling Scale (FS), Felt Arousal Scale (FAS), Tammen's single-item attentional focus scale, Borg's Perceived Exertion Scale (RPE) scale, and Experimental Testing Heart Rate (HR)

1) Shooters described their optimal sequence of actions for the execution of a single shot from the start Longitudinal design Aim: To help improve, stabilize, and optimize their performances during practice and competition (use of a multi-action plan intervention model)
2) They identified three or four of the most important core components to optimal performance 3) They assessed themselves by rating the quality of each core component 4) The core components were further assessed under conditions of increased distress and simulated competition
24 habitually active participants (14 men and 10 women) Mage $=21.3$ years, $S D=3.9 ; M_{B M I}=23.55$, $S D=2.14$

15 Italian shooters (Mage $=27.9$ years, $S D=8.1)$ of the London 2012 Olympics
No significant changes in mindfulness and dispositional flow were identified ( $C A M M$, was no significant interaction effect between time and group $(F[1,19]=0.44, p=.837), D F S-2$, no significant interaction effect between time and group $(F[1,19]=3.41, p=.08)$ However, the intervention had a positive impact on a range of physiological, cognitive, and performance parameters that included elements of mindfulness and flow.

The music-video condition elicited the highest levels of dissociation, lowest RPE, and most positive affective responses regardless of exercise intensity. Attentional manipulations influence psychological and psychophysical variables at exercise intensities above and below VT, and this effect is enhanced by the combined presentation of auditory and visual stimuli.

MAP improved individual's awareness of the core components and management of distressful conditions during shooting similar to those found in competition. Direct emotion, self-regulation treatments have been successfully applied in sports where performers were trained to either decrease or increase their levels of competitive self-confidence, anxiety, and pleasant/unpleasant emotional states to achieve their optimal states and to perform moptimally. Emotion-focused strategies can be used in combination with action-focused strategies to maintain or regain optimal performance.

confident and able to perceive challenges as opportunities rather than threats, are more likely to experience flow. Links between confidence and other correlates can emphasize its empowering effect. Firstly, confidence as a dimension of mental toughness appeared to be the most significant predictor of flow (Crust \& Swann, 2013; Hodge et al., 2009). Moreover, sources of confidence like achievement and self-regulation can enhance flow. Furthermore, high confidence is linked to absence of negative thoughts and emotions, optimal arousal, 
high-quality performance (Vealey \& Chase, 2008), effective practice and preparation (Vealey, Hayashi, Garner-Homan, \& Giaccobi, 1998), caddie (Lavallee, Bruce, \& Gorely, 2004), positive feedback (Bandura, 1997), commitment (Scanlan, Russell, Wilson, \& Scanlan, 2003). Last but not least, confidence emerged as a facilitator of flow in the "letting it happen" state (Swann et al., 2012; Swann et al., 2016). So, in comparison with Swann and his colleagues' review, the past five years' findings attempted a more explicit research of the factors that can enhance confidence towards the flow experience and the effects of its existence.

Another psychological correlate linked to the flow experience of athletes is performance anxiety. Participants found to have more anxiety when performing less challenging tasks (Fullager et al., 2013) and that is because in such tasks the analytic cognitive processes often have much more opportunities to interfere with the focused attention of flow and facilitate a distracted attention that is characteristic of anxiety (distraction theory; Beilock \& Carr, 2001; Lewis \& Linder, 1997). Flow and performance anxiety also found to be antithetical experiences (Fullager et al., 2013) and that both constructs are state-like rather than trait-like in a way that situational factors can be managed to enhance flow and reduce anxiety during performance in a task. Three more factors, the positive state (enjoyment, mentally positive, rhythm/tempo, comfort zone) (Swann et al., 2012), the calm and relaxed state (Swann et al., 2016) and commitment appeared to be strong tools in the controllability and therefore the occurrence of the flow experience. Commitment, however, isn't a factor highlighted in Swann and his colleagues' (2012) review. But in recent research, commitment found to be more important in individual sports rather than in team sports because the athlete has to manage his/her own training and performance rather than relying on a coach (Swann et al., 2015). Sport involvement and commitment found to have a debilitating effect on flow experiences of ranking list players, whereas not for lower skilled players (Koehn \& Morris, 2014). That supports the model of Kimiecik and Stein (1992) suggesting that competition importance and commitment might be crucial to explain athletes' involvement and individual differences in flow. To support, on the other hand, the experience of team commitment, a quite innovative study points out the mediating role of team commitment between team flow experience and team performance (Aubé et al., 2014; stated also on an individual level by Landhäuber \& Keller, 2012). The concept of team flow and team commitment is a new territory for research in sports environments.

Moving towards the flow occurrence, facilitators presented on Swann et al.'s review (2012), internal states were one of them. Under this general term the results of the present study identified the focus, arousal, goals and motivation correlates and how they found to facilitate athletes' flow experiences. Only a few studies have examined links within the achievement-motivation domain proposing that achievement-motivated individuals would be better benefited by competence environments (individualistic sports, e.g., athletics) and affiliationmotivated individuals would be fitted better in relatedness sports (team sports, e.g., volleyball). That fact was based on the finding that sports environments 
with a high level of competence and relatedness (Deci \& Ryan, 2002) characteristics and the interaction of environments and motives enhanced the prediction of flow (McClelland, 1985). Also, it was pointed out that flow in extreme endurance sports is mainly an achievement-related phenomenon. Moreover, performance-avoidance goals found to facilitate flow experiences and serve as regulatory tools that help those with a strong avoidance temperament cope with stressful achievement situations (Oertig et al., 2014). The combination of avoidance temperament (personality disposition) and performance-avoidance goals (motivation) would facilitate a regulatory process like flow that is commonly considered an optimal, even positive experience (Csikszentmihalyi, 1999). Both external (flow state) and internal associative attention strategies can be functional on a performance state (Bertollo et al., 2015). Especially internal attention can be functional when focusing on the core component of action and not on feelings of fatigue. All these findings about motivation, goals and attention came to shed light upon how these correlates should be triggered in order to enhance the flow experience and how they should be treated in a spectrum of individual differences. These connections upgrade the raw findings of Swann's et al.'s review proposing new tools towards flow (2012).

To end up with, a new research field emerged the previous years towards the understanding of flow in athletes and the enhancement of the tools towards this experience. That field referred to a few skills that can be applied through interventions and appeared to possibly facilitate the flow experience of athletes. Positive relationships between flow, confidence, imagery use and action control (Koehn et al., 2013a) proposed that confidence can be viewed as a mental skill (Vealey \& Chase, 2008), which can facilitate flow and that it can be incorporated in interventions to enhance flow. Imagery use can be also used to facilitate athlete's confidence and flow in competition settings. Action control and flow link suggest that action orientation can permeate on flow state level. An interaction between imagery use and confidence for flow state was proposed only for externally-paced (groundstroke task) and not in the self-paced task (service task) in tennis (Koehn et al., 2013b). That comes in opposition with Kimiecik and Stein's (1992) suggestion that flow can be facilitated in self-paced tasks due to of the self-control of the performance in that level.

\section{Limitations and Directions for Future Research}

It's important to emphasize and present some of the main limitations that emerged through this systematic review based upon the flow research in sports the past five years.

First of all, we present some limitations emphasizing on the method and design in those studies. In the spectrum of quantitative research that we summed up for this review, cross-sectional and retrospective design appeared to be unsuitable because they tend to provide only correlational and not causal relationships between variables. A cross-sectional design is static and time-bound, so it accesses the variables at a certain time and limits the control of the effect of in- 
dependent variables (Baron \& Kenny, 1986; Bauman, Sallis, Dzewaltowski, \& Owan, 2002) and a retrospective design can affect the participants' perception of the experience towards the performance outcome (Brewer, Van Raalte, Linder, \& Van Raalte, 1991). In qualitative flow research also, single interviews are not suitable and repeated measures are suggested (repeated interviews) and follow-ups.

Secondly, in the past five years of flow research in sports, some concerns about the sample and definition of flow have emerged. First of all, the fact that has a specific sample in most researches can influence the generalization of the findings to the broader population. It is also very important in order to establish the current effects of flow in research to approach multi-faceted operalizations and alternative definitions of flow, which till now hasn't been utilized (Fullager et al., 2013).

So, we propose some directions to these main difficulties in the categories of method-design-sample-definition. Firstly, we suggest that researchers should focus on the research of a design, like repeated measures, that can set the limits of the interpretations of the variables and highlight the causal connections. Secondly, an interesting alternative to ESM, which had also been proposed by Koehn (2013), is a short measure of flow, like FSS-2 that can be used at the changeovers of the performance. In quantitative flow research, it is also very important to control the task set up in a way that addresses the challenge factor (to be challenging for the person) and not just the task difficulty and to add to that, the duration of the performance is very important for an athlete to get into a deep flow experience. In qualitative research in flow, Swann and his colleagues (2016) proposed an event-focused approach that we represent too as an efficient option, ranging from the same day to one-week later interviews that can provide the chronology of the experience of flow in performance. Different levels of expertise (e.g. recreational athletes) and level of sports (e.g. fast paced, team sports) should be researched (Swann et al., 2016), as well as gender differences and the perspective of the coaches should be considered.

We also propose a few chapters and themes of research that it would be interesting to be investigated in the future. The concept of group flow is very important to be investigated much more towards the enhancement of flow between team members and how this phenomenon can affect the performance outcome and the build-up of effective interventions. Also, how the performance outcome can affect the experience of flow and if there is a certain type of athlete that can experience flow much more consciously. As well as how fatigue and energy levels can transform the experience of sports' flow. Furthermore, investigating the effect of energy levels in several cognitive mechanisms in older and young players and how they influence flow. And also, how injury can affect the experience of flow.

This systematic review also highlights the need of interventions based on personality correlates and dispositions and the motive type of the athlete in order to help increase the frequency and the quality of the flow experience in perfor- 
mance. Especially, more research should be conducted towards the understanding of the role of motives, goals and personality dispositions in flow in sports as well as how environmental factors influence the occurrence of flow. Interventions that use imagery functions can also enhance certain personality dispositions such as confidence and train mastery, control and effective preparation. Yoga and mindfulness interventions (Briegel-Jones et al., 2013), music and video influence (Hutchinson et al., 2014) can be effective interventions too, but much more research should be conducted.

\section{Conclusion}

Confidence, anxiety, positive, calm and relaxed state, commitment, motives, goals and attention were thought as the main factors influencing the appearance and occurrence of the flow experience. Also, motivation for performance, optimal focus and arousal, the "letting it go" state and altered and cognitive and kinesthetic perceptions modified the flow experience in sports' environments. Overall, flow appeared to have a strong connection with psychological correlates and internal states, like motivation, focus and arousal. The results of the present study add in the fields of research, theory, sport psychology and coach practice, and most of all in athletes' daily experience itself.

\section{Conflicts of Interest}

The authors declare no conflicts of interest regarding the publication of this paper.

\section{References}

Aubé, C., Brunelle, E., \& Rousseau, V. (2014). Flow Experience and Team Performance: The Role of Team Goal Commitment and Information Exchange. Motivation and Emotion, 38, 120-130. https://doi.org/10.1007/s11031-013-9365-2

Bandura, A. (1997). Self-Efficacy: The Exercise of Control. New York: Freeman.

Baron, R. M., \& Kenny, D. A. (1986). The Moderator-Mediator Variable Distinction in Social Psychological Research: Conceptual, Strategic, and Statistical Considerations. Journal of Personality and Social Psychology, 51, 1173. https://doi.org/10.1037/0022-3514.51.6.1173

Bauman, A. E., Sallis, J. F., Dzewaltowski, D. A., \& Owen, N. (2002). Toward a Better Understanding of the Influences on Physical Activity: The Role of Determinants, Correlates, Causal Variables, Mediators, Moderators, and Confounders. American Journal of Preventive Medicine, 23, 5-14. https://doi.org/10.1016/S0749-3797(02)00469-5

Beilock, S. L., \& Carr, T. H. (2001). On the Fragility of Skilled Performance: What Governs Choking under Pressure? Journal of Experimental Psychology: General, 130, 701. https://doi.org/10.1037/0096-3445.130.4.701

Bertollo, M., di Fronso, S., Filho, E., Lamberti, V., Ripari, P., Reis, V. M., \& Robazza, C. (2015). To Focus or Not to Focus: Is Attention on the Core Components of Action Beneficial for Cycling Performance? The Sport Psychologist, 29, 110-119. https://doi.org/10.1123/tsp.2014-0046

Bortoli, L., Bertollo, M., Hanin, Y., \& Robazza, C. (2012). Striving for Excellence: A Mul- 
ti-Action Plan Intervention Model for Shooters. Psychology of Sport and Exercise, 13, 693-701. https://doi.org/10.1016/j.psychsport.2012.04.006

Brewer, B. W., Van Raalte, J. L., Linder, D. E., \& Van Raalte, N. S. (1991). Peak Performance and the Perils of Retrospective Introspection. Journal of Sport and Exercise Psychology, 13, 227-238. https://doi.org/10.1123/jsep.13.3.227

Briegel-Jones, R. M., Knowles, Z., Eubank, M. R., Giannoulatos, K., \& Elliot, D. (2013). A Preliminary Investigation into the Effect of Yoga Practice on Mindfulness and Flow in Elite Youth Swimmers. The Sport Psychologist, 27, 349-359. https://doi.org/10.1123/tsp.27.4.349

Crust, L., \& Swann, C. (2013). The Relationship between Mental Toughness and Dispositional Flow. European Journal of Sport Science, 13, 215-220. https://doi.org/10.1080/17461391.2011.635698

Csikszentmihalyi, M. (1996). Creativity. New York: HarperCollins.

Csikszentmihalyi, M. (1999), "If We Are So Rich, Why Aren't We Happy?" American Psychologist, 54, 821-827. https://doi.org/10.1037/0003-066X.54.10.821

Csikszentmihalyi, M. (2009). Flow. In S. Lopez (Ed.), The Encyclopedia of Positive Psychology (pp. 394-400). Chichester: Blackwell Publishing Ltd.

Csikszentmihalyi, M., \& Csikszentmihalyi, I. (Eds.) (1988). Optimal Experience. Cambridge: Cambridge University Press. https://doi.org/10.1017/CBO9780511621956

Csikszentmihalyi, M., Rathunde, K., \& Whalen, S. (1993). Talented Teenagers: A Longitudinal Study of Their Development. New York, NY: Cambridge University Press.

Deci, E. L., \& Ryan, R. M. (2000). The "What" and "Why" of Goal Pursuits: Human Needs and the Self-Determination of Behavior. Psychological Inquiry, 11, 227-268. https://doi.org/10.1207/S15327965PLI1104_01

Deci, E. L., \& Ryan, R. M. (2002). Handbook of Self-Determination Research. Rochester, NY: University of Rochester Press.

Fullager, C. J., Knight, P. A., \& Sovern, H. S. (2013). Challenge/Skill Balance, Flow and Performance. Applied Psychology: An International Review, 62, 236-259. https://doi.org/10.1111/j.1464-0597.2012.00494.x

Hefferon, K., \& Boniwell, I. (2011). Positive Psychology: Theory, Research and Applications. London: McGraw-Hill. https://doi.org/10.1177/1071181311551098

Hodge, K., Lonsdale, C., \& Jackson, S. A. (2009). Athlete Engagement in Elite Sport: An Exploratory Investigation of Antecedents and Consequences. The Sport Psychologist, 23, 186-202. https://doi.org/10.1123/tsp.23.2.186

Hutchinson, J. C., Karageorghis, C. I., \& Jones, L. (2014). See Hear: Psychological Effects of Music and Music-Video during Treadmill Running. Annals of Behavioral Medicine, 49, 199-211. https://doi.org/10.1007/s12160-014-9647-2

Jackman, P., Van Hout, M., Lane, A., \& Fitzpatrick, G. (2014). Experiences of Flow in Jockeys during Flat-Race Conditions. International Journal of Sport and Exercise Psychology, 13, 205-223.

Jackson, S., \& Csikszentmihalyi, M. (1999). Flow in Sports: The Keys to Optimal Experiences and Performances. Champaign: Human Kinetics.

Jackson, S. A. (1995). Factors Influencing the Occurrence of Flow State in Elite Athletes. Journal of Applied Sport Psychology, 7, 138-166.

https://doi.org/10.1080/10413209508406962

Jackson, S., \& Eklund, R. (2012). Flow. In G. Tenenbaum, R. Eklund, \& A. Kamata (Eds.), Measurement in Sport and Exercise Psychology (pp. 349-358). Champaign: Human Kinetics. 
Jackson, S. A., \& Roberts, G. C. (1992). Positive Performance States of Athletes: Toward a Conceptual Understanding of Peak Performance. The Sport Psychologist, 6, 156-171. https://doi.org/10.1123/tsp.6.2.156

Jackson, S. A., Ford, S. K., Kimiecik, J. C., \& Marsh, H. W. (1998). Psychological Correlates of Flow in Sport. Journal of Sport and exercise Psychology, 20, 358-378. https://doi.org/10.1123/jsep.20.4.358

Jackson, S. A., Thomas, P. R., Marsh, H. W., \& Smethurst, C. J. (2001). Relationships between Flow, Self-Concept, Psychological Skills, and Performance. Journal of Applied Sport Psychology, 13, 129-153. https://doi.org/10.1080/104132001753149865

Kent, M. (2006). The Oxford Dictionary of Sports Science and Medicine (3rd ed.). Oxford: Oxford University Press.

Kimiecik, J. C., \& Stein, G. L. (1992). Examining Flow Experiences in Sport Contexts: Conceptual Issues and Methodological Concerns. Journal of Applied Sport Psychology, 4, 144-160. https://doi.org/10.1080/10413209208406458

Koehn, S., \& Morris, T. (2014). The Effect of Performance Context and Skill Level on the Frequency of Flow Experiences. European Journal of Sport Science, 14, S478-S486. https://doi.org/10.1080/17461391.2012.718364

Koehn, S. (2013). Effects of Confidence and Anxiety on Flow State in Competition. European Journal of Sport Science, 13, 543-550. https://doi.org/10.1080/17461391.2012.746731

Koehn, S., Morris, T., \& Watt, A. P. (2013a). Correlates of Dispositional and State Flow in Tennis Competition. Journal of Applied Sport Psychology, 25, 354-369.

Koehn, S., Morris, T., \& Watt, A. P. (2013b). Flow State in Self-Paced and Externally-Paced Performance Contexts: An Examination of the Flow Model. Psychology of Sport and Exercise, 14, 787-795.

Koehn, S., Pearce, A. J., \& Morris, T. (2013). The Integrated Model of Sport Confidence: A Canonical Correlation and Mediational Analysis. Journal of Sport and Exercise Psychology, 35, 644-654. https://doi.org/10.1123/jsep.35.6.644

Landhäuber, A., \& Keller, J. (2012). Flow and Its Affective, Cognitive, and Performance-Related Consequences. In S. Engeser (Ed.), Advances in Flow Research (pp. 65-85). New York, NY: Springer.

Lavallee, D., Bruce, D., \& Gorely, T. (2004). The Golfer-Caddie Partnership: An Exploratory Investigation into the Role of the Caddie. Athletic Insight: The Online Journal of Sport Psychology, 6.

Lewis, B. P., \& Linder, D. E. (1997). Thinking about Choking? Attentional Processes and Paradoxical Performance. Personality and Social Psychology Bulletin, 23, 937-944. https://doi.org/10.1177/0146167297239003

McClelland, D. C. (1985). How Motives, Skills, and Values Determine What People Do. American Psychologist, 40, 812-825. https://doi.org/10.1037/0003-066X.40.7.812

Oertig, D., Schüler, J., Brandstätter, V., \& Augustine, A. A. (2014). The Influence of Avoidance Temperament and Avoidance-Based Achievement Goals on Flow. Journal of Personality, 82, 171-181. https://doi.org/10.1111/jopy.12043

Orlick, T., \& Partington, J. (1988). Mental Links to Excellence. The Sport Psychologist, 2, 105-130. https://doi.org/10.1123/tsp.2.2.105

Scanlan, T. K., Russell, D. G., Wilson, N. C., \& Scanlan, L. A. (2003). Project on Elite Athlete Commitment (PEAK): I. Introduction and Methodology. Journal of Sport and Exercise Psychology, 25, 360-376. https://doi.org/10.1123/jsep.25.3.360

Schüler, J., \& Brandstätter, V. (2013). How Basic Need Satisfaction and Dispositional Mo- 
tives Interact in Predicting Flow Experience in Sport. Journal of Applied Social Psychology, 43, 687-705. https://doi.org/10.1111/j.1559-1816.2013.01045.x

Schüler, J., Wegner, M., \& Knechtle, B. (2014). Implicit Motives and Basic Need Satisfaction in Extreme Endurance Sports. Journal of Sport and Exercise Psychology, 36, 293-302. https://doi.org/10.1123/jsep.2013-0191

Stavrou, N. A., \& Zervas, Y. (2004). Confirmatory Factor Analysis of the Flow State Scale in Sports. International Journal of Sport and Exercise Psychology, 2, 161-181. https://doi.org/10.1080/1612197X.2004.9671739

Swann, C. (2016). Flow in Sport. In Flow Experience (pp. 51-64). Berlin: Springer International Publishing. https://doi.org/10.1007/978-3-319-28634-1_4

Swann, C., Crust, L., Keegan, R., Piggott, D., \& Hemmings, B. (2015). An Inductive Exploration into the Flow Experiences of European Tour Golfers. Qualitative Research in Sport, Exercise and Health, 7, 210-234. https://doi.org/10.1080/2159676X.2014.926969

Swann, C., Keegan, R., Piggott, D., \& Crust, L. (2012). A Systematic Review of the Experience, Occurrence and Controllability of Flow in Elite Sport. Psychology of Sport and Exercise, 13, 807-819. https://doi.org/10.1016/j.psychsport.2012.05.006

Swann, C., Keegan, R., Crust, L., \& Piggott, D. (2016). Psychological States Underlying Excellent Performance in Professional Golfers: "Letting It Happen" vs. "Making It Happen". Psychology of Sport and Exercise, 23, 101-113.

https://doi.org/10.1016/j.psychsport.2015.10.008

Swann, C., Keegan, R., Piggott, D., Crust, L., \& Smith, M. F. (2012). Exploring Flow Occurrence in Elite Golf. Athletic Insight, 4, 171.

Swann, C., Piggott, D., Crust, L., Keegan, R., \& Hemmings, B. (2015). Exploring the Interactions Underlying Flow States: A Connecting Analysis of Flow Occurrence in European Tour Golfers. Psychology of Sport and Exercise, 16, 60-69. https://doi.org/10.1016/j.psychsport.2014.09.007

Vealey, R. S., \& Chase, M. A. (2008). Self-Confidence in Sport. In T. S. Horn (Ed.), Advances in Sport Psychology (3rd ed., pp. 66-97). Champaign, IL: Human Kinetics.

Vealey, R. S., Garner-Holman, M., Hayashi, S. W., \& Giacobbi, P. (1998). Sources of Sport-Confidence: Conceptualization and Instrument Development. Journal of Sport and Exercise Psychology, 20, 54-80. https://doi.org/10.1123/jsep.20.1.54 